\title{
Retraction
}

\section{Retracted: Induction of Heat Shock Protein Expression in Cervical Epithelial Cells by Human Semen}

\author{
Infectious Diseases in Obstetrics and Gynecology \\ Received 29 October 2017; Accepted 29 October 2017; Published 13 November 2017 \\ Copyright (c) 2017 Infectious Diseases in Obstetrics and Gynecology. This is an open access article distributed under the Creative \\ Commons Attribution License, which permits unrestricted use, distribution, and reproduction in any medium, provided the \\ original work is properly cited.
}

Infectious Diseases in Obstetrics and Gynecology has retracted the article titled "Induction of Heat Shock Protein Expression in Cervical Epithelial Cells by Human Semen" [1]. The article was found to report the same results, without citation, as the following published article: J. Jeremias, S. S. David, M. Toth, S. S. Witkin, "Induction of messenger RNA for the $70 \mathrm{kDa}$ heat shock protein in HeLa cells and the human endocervix following exposure to semen: implications for antisperm antibody production and susceptibility to sexually transmitted infections," Human Reproduction (1997) 12 (9): 1915-1919. DOI: https://doi.org/10.1093/humrep/12.9.1915 [2]. The last author does not approve of retraction and the other authors could not be contacted.

\section{References}

[1] J. C. Jeremias, A. M. Bongiovanni, and S. S. Witkin, "Induction of heat shock protein expression in cervical epithelial cells by human semen," Infectious Diseases in Obstetrics and Gynecology, vol. 7, no. 1-2, pp. 17-22, 1999.

[2] J. Jeremias, S. S. David, M. Toth, and S. S. Witkin, "Induction of messenger RNA for the $70 \mathrm{kDa}$ heat shock protein in HeLa cells and the human endocervix following exposure to semen: implications for antisperm antibody production and susceptibility to sexually transmitted infections," Human Reproduction, vol. 12, no. 9, pp. 1915-1919, 1997. 